\title{
Verification of Potassium, Zinc and Boron Fertilizer on Yield of Wheat (Triticum aestivum) in Jamma and Meket Districts of East Amhara
}

\author{
Habtemariam Teshome* Kassa Sisay Samuel Adissie \\ Tadesse Hailu Muluken Lebay Tesfaye Wubu \\ 1.Sirinka Agricultural Research Center, \\ 2.Amhara Regional Agricultural Research Institute (ARARI) \\ Corresponding: Habtemariam Teshome, Sirinka Agricultural Research Center, P.O. Box 74, Woldia
}

\begin{abstract}
Soil fertility map of the region developed by ATA and Ministry of Agriculture and Natural Resources indicates $100 \%$ of the Jamma and Meket district shows potassium deficiency. In addition to potassium $100 \%$ of Jamma districts and more than of $98 \%$ of Meket district also shows both NPSB and NPSBZn deficiency. This study was conducted in Eastern Amhara National, Regional State of Meket and Jamma districts in the 2017 cropping season to verify crop responses to potassium, Boron and Zinc fertilizers visa- via the soil fertility map of the districts developed by ATA and Ministry of Agriculture and Natural Resources. Five sites per district were selected for the study. The test crop was wheat (Dinkenesh). The treatments were: NPS, NPSK, NPSBZn and NPSKBZn. Treatments were replicated three times per site and the design was RCBD. Recommended NP was used uniformly for all treatments. The collected data were subjected to analysis of variance using SAS version 9. The Result reveald that there was no statistical significance yield difference $(p>0.05)$ between potassium, boron and zinc treated plots and recommended NP plots. For all sites the finding was unrelated to the developed soil fertility map. Therefore; it is unjustified to use K, B and Zn fertilizers for the study crops and areas.
\end{abstract}

Keywords: Boron fertilizer, Potassium fertilizer, soil fertility map, Zinc fertilizer

DOI: $10.7176 / \mathrm{JEES} / 10-3-05$

Publication date:March $31^{\text {st }} 2020$

\section{Introduction}

Ethiopia is endowed with abundant agricultural resources and has diverse ecological zones. The two dominant agricultural systems in Ethiopia are the mixed agriculture of the highlands, where both crops and livestock production are integrated, and pastoralism in the lowlands. Agriculture in Ethiopia accounts for about $34.8 \%$ of the gross domestic product (GDP) (CIA World Factbook 2019). In Ethiopia there is a positive response to nitrogen and phosphorous fertilizer applications for most crops under all agro ecologies. However; there has been a lack of crop response to potassium fertilizer (Murphy, 1968; Tadele et al, 2010; Tadele et al, 2018). Against the finding of these authors $94 \%$ of the Amhara National, Regional State shows potassium deficiency, according to the soil fertility map of the region developed by ATA and Ministry of Agriculture and Natural Resources (2016) and Tena and Beyene (2011). The soil fertility map shows potassium were deficiet in $100 \%$ of Jamma and Dawa-cheffa districts and also NPSBZn + NPSB were 100\% deficient in Jamma and about 99\% of Dawa-cheffa districts inaddition to potassium (ATA and MoANR,2016).

Ethiopian soils are supposed to be rich enough to support the crop demand of potassium based on the findings of crop responses to potassium fertilizer carried out before this study (Tadele et al., 2018; Abebe et al., 2019, unpublished). Blended fertilizers which contain potassium were introduced in different ways in the country starting from 2014 as abalanced fertilizer (Brhane et al, 2017) to all areas of the region including to Jamma and Meket districts. ATA suggests to apply $100 \mathrm{~kg}$ of potassium fertilizer throughout the districts with out considering the crop type and agroecological zones. based on this the regional agriculture bereau forced to distribute potassium fertilizers to the farmer in addition to nitrogen and phosphorous.

Besides this the Amhara agricultural research institutes give emphasise to this new fertilizers and propose regional activities to support the soil fertility map based on crop responses. Therefore; this research was designed to verify the crop response to potassium, boron and zinc visa via the soil fertility map of the districts.

\section{Material and methods}

\subsection{Study site}

The research was conducted in a farmer's field at Meket and Jamma districts in the Eastern Amhara region in 2017/18 main rainy season. Jamma is located about $260 \mathrm{~km}$ away from the capital city, Addis Ababa, in the north east direction and at an altitude of 2630 meters above sea level (masl). The geographical location of the district lies between $10^{\circ} 23^{\prime}$ to $10^{\circ} 27^{\prime} \mathrm{N}$ latitudes and $39^{\circ} 07^{\prime}$ to $39^{\circ} 24^{\prime}$ E longitudes in South Wollo Zone of the Amhara National Regional State. The dominant soil type of the district is Vertisols. The soil is characterized by poor 
drainage and difficulty to work, but high potential for wheat production with proper soil management. Meket is located in the western parts of North Wollo Zone. it is bordered in the south by Wadla and Dawunt districts, in the west by Lay Gaint and Tach Gaint districts , in the northwest by Bugna district, in the north by Lasta district, in the northeast by Gidan district, and in the east by Gubalafto district. The altitude of the district reaches to 2650 meter above sea level (masl). The district receives a unimodal type of rain fall with an average annual rainfall of $1105 \mathrm{~mm}$. The soil is brown in color and acidic in reaction.

Recommended Fertilizers for Meket Woreda

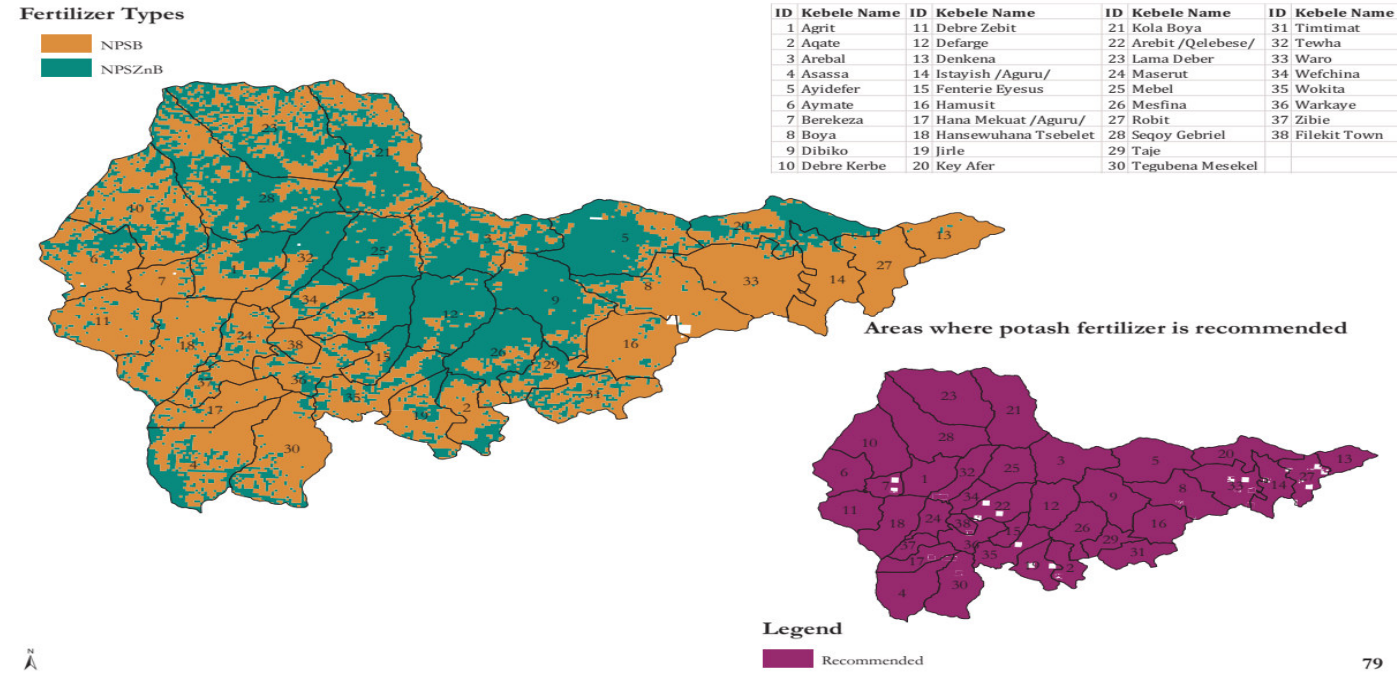

Figure 1. Fertilizer recommended areas of meket district(source,ATA and MoANR,2016).
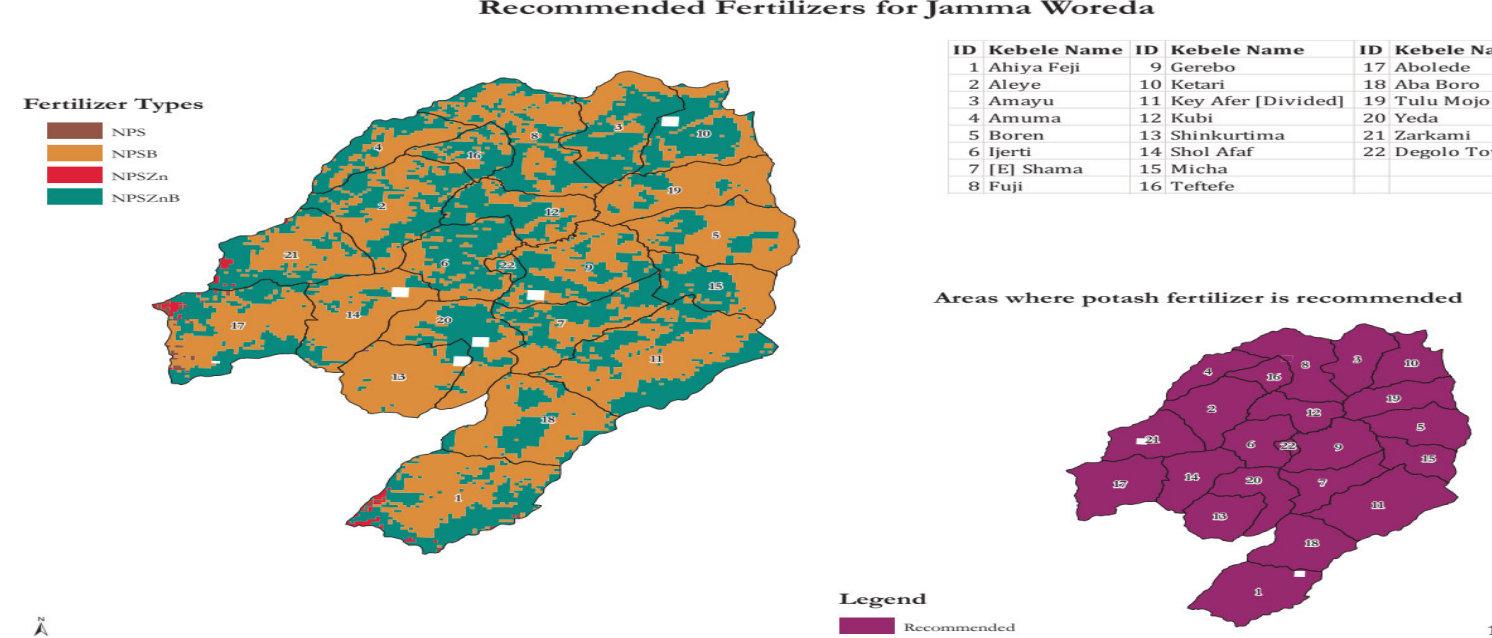

Figure,2. Fertilizer recommended areas of Jamma district (source,ATA and MoANR,2016).

\subsection{Treatment setup}

The treatments used for the research were:

1. NPS

2. NPSK

3. NPSBZn

4. NPSKBZn

Treatments were replicated three times per site and the design was RCBD. Recommended NP was used uniformly for all treatments. Nitrogen, $69 \mathrm{~kg} / \mathrm{ha}$ for Meket and $115 \mathrm{~kg} / \mathrm{ha}$ for Jamma was used. While, $69 \mathrm{~kg} / \mathrm{ha} P$ ${ }_{2} \mathrm{O}_{5}$ for both districts was used. The rate of $\mathrm{KCl}$ was $150 \mathrm{~kg} / \mathrm{ha}$. Nitrogen was applied by splitting half at planting and half at tillering. The whole rates of phosphorous and potassium chloride was applied at planting. Foliar application of B and $\mathrm{Zn}$ fertilizer at a rate of $1 \mathrm{~kg} / \mathrm{ha}$ Borax and $1 \mathrm{~kg} / \mathrm{ha}$ Zinc sulphate was used.

The plot size was $25 \mathrm{~m}^{2}(5 \mathrm{~m} * 5 \mathrm{~m})$ for Meket and $24 \mathrm{~m}^{2}(4.8 \mathrm{~m} * 5 \mathrm{~m})$ for Jamma. At Jamma broad bed furrow with $80 \mathrm{~cm}$ by $40 \mathrm{~cm}$ was used. The space between plots and replications were $0.5 \mathrm{~m}$ and $1 \mathrm{~m}$ respectively. Soil and crop management were applied uniformly to all treatments. The variety was Dinkenesh with the seed rate 
of $125 \mathrm{~kg} / \mathrm{ha}$.

\subsection{Soil Sampling and Analysis}

Composite soil samples at a depth of 0-20 cm were collected from each farm at planting. Samples were air-dried and ground to pass a 2-mm sieve and $0.5 \mathrm{~mm}$ sieve (for total $\mathrm{N}$ ) before analysis. Soil texture was determined by bouyoucos hydrometer method. The $\mathrm{pH}$ of the soils was measured in water (1:2.5 soils to water ratio). The organic carbon content of the soil was determined following Walkley and Black procedures (1934). The total nitrogen was determined by Kjeldahl method (Bremner \& Mulvaney, 1982). The available soil phosphorus was determined by the Olsen method (1954). Exchangeable potassium was extracted by ammonium acetate at $\mathrm{pH} 7$ (sahalmedhin and Taye, 2000) and determined by Atomic absorption spectrometer.

\subsection{Crop data}

Plant height was measured at maturity from five random plant samples of the harvestable rows from the ground to the tip of the spike. Grain yield was collected from the central rows while, the two border rows were not included. The moisture content of the grain was collected simultaneously with the grain yield and finally adjusted to the moisture content of $12.5 \%$.

\subsection{Data analysis}

Collected data were subjected to analysis of variance to evaluate the degree of variations between treatments using SAS version 9.0

\section{Results and discussion}

\subsection{Physico-chemical properties of the soil}

The results of soil analysis showed that for both districts the soil was clay in texture. The total nitrogen ranged from $0.1 \%$ to $0.2 \%$ and $0.08 \%$ to $0.15 \%$ for Meket and Jamma respectively, and this range is from low to medium (Tekaligne et al., 1991). The soil organic matter in Meket ranged from 1.6\% to $3.8 \%$ and for Jamma ranged from $0.67 \%-1.55 \%$. The level of soil organic matter was in a category of low to medium for Meket and low to Jamma according to Berhanu (1980). The available phosphorus was ranged from 23.05ppm to 31.15ppm for Meket and from $39.4 \mathrm{ppm}$ to $54.8 \mathrm{ppm}$ for Jamma. For both study sites the availability of phosphorous is categorized as very high (Marx et al., 1999). The exchangeable potassium was 1.703 to $5.810 \mathrm{meq} / 100 \mathrm{~g}$ soil for Meket and 4.861 to $6.003 \mathrm{meq} / 100 \mathrm{~g}$ soil for Jamma. The level of potassium for the two districts was very high $(\mathrm{FAO}, 2006)$ and hence crop response to potassium is very unlikely. The soil reaction $(\mathrm{pH})$ of the two districts was ranging from 5.9-6.3 and 6.4-6.77 for Meket and Jamma respectively.

\subsection{Yield response}

The results of the research showed that there was no statistical significance difference $(\mathrm{p}<0.05)$ among and between treatments for both districts (Table 1,2,3 and 4). This finding is in line with previous results for refining studies of potassium, boron and zinc and for the map validation study, which was conducted in the region (Abebe et al., 2019; Tadele et al., 2018). The result is also supported by our soil analysis results that showed the level of potassium was above the critical limit. Adding potassium, boron and zinc fertilizers did not bring any observable yield advantages over recommended NP fertilizers.

Table 1. Effect of treatments on grain yield $\left(\mathrm{kgha}^{-1}\right)$ at Jamma

\begin{tabular}{lcccccc}
\hline Treatment & Farm 1 & Farm 2 & Farm 3 & Farm 4 & Farm5 & Mean \\
\hline NPS & 2991 & 3014 & 3798 & 2834 & 2925 & 3112 \\
NPSK & 3043 & 3213 & 3565 & 2657 & 3054 & 3106 \\
NPSBZn & 2663 & 3179 & 3569 & 2922 & 2823 & 3032 \\
NPSKBZn & 2986 & 3186 & 3799 & 2684 & 3305 & 3192 \\
\hline LSD $(5 \%)$ & NS & NS & NS & NS & NS & NS \\
CV $(\%)$ & 13.1 & 5.66 & 8.4 & 12.88 & 11.02 & 14.0 \\
\hline
\end{tabular}

Table 2. Effect of treatments on biomass yield $\left(\mathrm{kgha}^{-1}\right)$ at Jamma

\begin{tabular}{lcccccc}
\hline Treatment & Farm 1 & Farm 2 & Farm 3 & Farm 4 & Farm5 & Mean \\
\hline NPS & 7722 & 7611 & 9556 & 7111 & 7889 & 7978 \\
NPSK & 7556 & 8000 & 8611 & 6778 & 7944 & 7778 \\
NPSBZn & 6833 & 8056 & 9278 & 7444 & 7444 & 7811 \\
NPSKBZn & 7611 & 7722 & 9222 & 6833 & 8611 & 8000 \\
\hline LSD $(5 \%)$ & NS & NS & NS & NS & NS & NS \\
CV $(\%)$ & 12.93 & 6.36 & 7.9 & 9.76 & 11.51 & 13.74 \\
\hline
\end{tabular}


Table 3. Effect of treatments on grain yield $\left(\mathrm{kgha}^{-1}\right)$ at Meket

\begin{tabular}{lcccccc}
\hline Treatment & Farm 1 & Farm 2 & Farm 3 & Farm 4 & Farm 5 & Mean \\
\hline NPS & 2885 & 3011 & 3787 & 1943 & 2906 & 2906 \\
NPSK & 2485 & 3611 & 3979 & 2136 & 2964 & 3035 \\
NPSBZn & 3070 & 2944 & 3883 & 1877 & 2550 & 2865 \\
NPSKBZn & 2722 & 3033 & 3882 & 2091 & 2679 & 2881 \\
\hline LSD $(5 \%)$ & NS & NS & NS & NS & NS & NS \\
CV $(\%)$ & 24.32 & 17.62 & 4.88 & 20.12 & 13.79 & 27.74 \\
\hline
\end{tabular}

Table 4. Effect of treatments on biomass yield $\left(\mathrm{kgha}^{-1}\right)$ at Meket

\begin{tabular}{lcccccc}
\hline Treatment & Farm 1 & Farm 2 & Farm 3 & Farm 4 & Farm 5 & Combined \\
\hline NPS & 8174 & 7275 & 10116 & 5159 & 7855 & 7716 \\
NPSK & 7391 & 8588 & 10652 & 5870 & 8290 & 8158 \\
NPSBZn & 8841 & 7333 & 9812 & 5696 & 6826 & 7701 \\
NPSKBZn & 8087 & 8529 & 10638 & 5768 & 7739 & 8152 \\
\hline LSD (5\%) & NS & NS & NS & NS & NS & NS \\
CV $(\%)$ & 20.8 & 17.45 & 4.42 & 12.5 & 13.52 & 24.59 \\
\hline
\end{tabular}

The finding of this research did not support the soil fertility map of the districts developed by ATA and Ministry of Agriculture and Natural Resource (2016) as well as $100 \mathrm{~kg}$ of potassium chloride per hectar recommendations made by IPI, (2016) for all soils of Ethiopia. It was also not in line with the findings of Wassie and Tekalgn (2013) who claimed $41 \%$ yield increase over the control by using potassium fertilizer. In our case there were some cases where application of potassium as well as boron and zinc fertilizers resulted in lower yields than the control (recommended NP) even if it was insignificant. Brhane et al., (2017) also reported maximum yield of wheat from maximum input of potassium $(90 \mathrm{~kg} \mathrm{~K} 2 \mathrm{O} / \mathrm{ha}$ ) which did not bring any biological yield increment with the same rates of potassium under this research. Piri, I., (2012) reported that foliar application of micronutrient increased grain yield but it is not observed in these research.

For soils that are deficient in potassium and micronutrients including zinc and boron the yield of crops increased through proper application of the nutrients (Chaudry et al., 2007; Dash et al., 2015; Gitte et al., 2005; Nadim et, al., 2012; Nataraja et al., 2006; Sultana et, al., 2016). Among micronutrients, Zinc (Zn) and Boron (B) play a key role in pollination and seed set processes; so that their deficiency can cause to decrease in seed formation and subsequent yield reduction. This effect of micronutrient is not observed in this research. It is clear that the importance of potassium and other micronutrients including zinc and boron for the production of crops, however; with the current status of wheat responses for the study districts and other similar areas with similar soil and agroecological properties application of these nutrients does not give any biological benefits. The implication of our findings as witnessed by the results of soil potassium, the soil supplies sufficient amount of these nutrients for the production of wheat. Therefore; it is unwise to use these fertilizers for the production of wheat under the current situation. The government should give focus on NP fertilizers to increase agricultural production and productivity of wheat.

Application of potassium, zinc and boron fertilizers are therefore additional costs for the farmers without increasing the productivity of wheat, which is the major crop for the study areas and wheat is one of the voracious crop that could indicate any deficiency of nutrients for its optimal production. Therefore; the map developed by ATA and the ministry of agriculture and natural resource should not be used directly as it did not show any relation with potassium, boron and zinc applications.

\section{Conclusion and Recommendation}

The over all result of this research showed that application of $\mathrm{K}, \mathrm{B}$ and $\mathrm{Zn}$ contained fertilizers did not bring significant yield increment over recommended NP fertilizer. This indicates application of recommended NP fertilizer without the addition of $\mathrm{K}, \mathrm{B}$ and $\mathrm{Zn}$ fertilizers is required to increase production and productivity of wheat in the study districts. So that K, B and Zn were not potentially yield limiting nutrients in the study sites and these nutrients were sufficient to support good crop growth for wheat in both areas where these experiments were conducted.

This study confirmed that for this time no need of potassium, Zinc and Boron fertilizer in the mentioned study area. Moreover, crop response to new fertilizers and the soil fertility status must be monitored as they will be expected to be yield limiting in the future. Therefore, potassium, zinc and boron contain fertilizers should not be used for the study districts and the soil fertility map should be revised. For the future research should be done to monitor the status of potassium and micronutrients in the district.

\section{References}

A.E. johnston; European fertilizer manufacturing association (EFMA),2003. 
Berhanu Debele. 1980. The physical criteria and their rating proposed for land evaluation in the highland region of Ethiopia. Land use planning and regulatory department, Ministry of Agriculture. Addis Ababa, Ethiopia

Bouyoucos, G. J. (1962). Hydrometer method improved for making particle size analyses of soils. Agronomy Journal, 54, 464-465.

Brhane Hagos, Mamo Tekalegn, Teka Kassa (2017) Potassium Fertilization and its Level on Wheat (Triticum aestivum) Yield in Shallow Depth Soils of Northern Ethiopia. J Fertil Pestic 8: 182. doi:10.4172/24712728.1000182.

Chaudry, E.H., V. Timmer, A.S. Javed and M.T. Siddique. 2007. Wheat response to micronutrients in rain-fed areas of Punjab. Soil \& Environ. 26: 97-101.

Dash A.K., Singh H.K., Mahakud T., Pradhan K.C. and Jena D. (2015). Interaction Effect of Nitrogen, Phosphorus, Potassium with Sulphur, Boron and Zinc on Yield and Nutrient Uptake by Rice Under Rice - Rice Cropping System in Inceptisol of Coastal Odisha . Int. Res. J. Agric. Sci. Soil Sci. 5(1):14-21

E. S. Marx, J. Hart, and R. G. Stevens, "Soil Test Interpretation Guide," Oregon State Univ. Serv., 1996.

Gitte, A.N., Patil, S.R. and Tike, M.A., 2005. Influence of zinc and boron on biochemical and yield characteristics of sunflower. Indian journal of plant physiology, 10(4), pp.400-403.

Haile, Wassie. And Mamo, Tekaligne. 2013. The effect of potassium on the yields of potato and wheat grown on the acidic soils of Chencha and Hagere Selam in Southern Ethiopia. International Potash Institute Research Findings, 35, pp.3-8.

International potash Institute (IPI),2016.Technical manual on potash fertilizer.

Mandal, A., A.K. Patra, D. Singh, A. Swarup and R.E. Masto. 2007. Effect of long-term application of manure and fertilizer on biological and biochemical activities in soil during crop development stages. Bioresour. Technol. 98: 3585-3592.

Ministry of Agriculture \& Natural Resources and Agricultural Transformation Agency of Ethiopia. 2016. Soil Fertility Status and Fertilizer Recommendation Atlas of Amhara National Regional State, Ethiopia: 297 pages.

Murphy, H. F. 1968. A report on fertility status and other data on some soils of Ethiopia. Experimental Station Bulletin No. 44. Hailesilassie College of Agriculture. Oklahoma State University, 551P.

Nadim, M.A., Awan, I.U., Baloch, M.S., Khan, E.A., Naveed, K. and Khan, M.A., 2012. Response of wheat (Triticum aestivum L.) to different micronutrients and their application methods. J. Anim. Plant Sci, 22(1), pp.113-119.

Nataraja, T.H., A.S. Halepyati, B.T. Pujari and B.K. Desai. 2006. Influence of phosphorus levels and micronutrients on the physiological parameters of wheat. Karnataka J. Agri. Sci. 19: 685-687.

Olsen, S. R. (1954). Estimation of available phosphorus in soils by extraction with sodium bicarbonate. Washington: United States Department of Agriculture.

Piri, I., 2012. Effect of phosphorus fertilizer and micronutrients foliar application on sorghum yield. Annals of Biological Research, 3(8), pp.3998-4001.

Sultana, S., Naser, H.M., Akhter, S. and Begum, R.A., 2016. Effectiveness of soil and foliar applications of zinc and boron on the yield of tomato. Bangladesh Journal of Agricultural Research, 41(3), pp.411-418.

Tadele Amare, Zerfu Bazie, Erkihun Alemu, Asmare Wubet, Birhanu Agumas, Mengstu Muchie,Tesfaye Feysa and Desalew fentie,2018.Crop response to balance nutrient application in north western Ethiopia. Blue Nile Journal of Agricultural Research(1),pp1-14.

Tadele Amare,Tesfaye Feysa and yihenew G/Selassie. 2010. Response of maize, malt barely and tomato to potassium. In; Birru Yitaferu,Teshome Tessema, Zewdu Ayalew (eds.). Procedings of the third Annual Regional Conference on Completed Research activities on soil and water management, Forestry and Agricultural Mechanization 1-4 september 2008, Amhara regional agricultural research institute ARARI, bahirdar,Ethiopia,pp 67-75.

Tena, W. and Beyene, S., 2011. Identification of growth limiting nutrient (s) in alfisols: Soil physico-chemical properties, nutrient concentrations and biomass yield of maize. American journal of plant nutrition and fertilization technology, 1(1), pp.23-35.

Walkley, A., \& Black, I. A. (1934). An examination of the Degtjareff method for determining soil organic matter, and a proposed modifcation of the chromic acid titration method. Soil Science, 37, 29-38. 